\title{
SERVANT LEADERSHIP AND ITS RELATION TO WORK PERFORMANCE
}

\section{Gašková, J.}

Jana Gašková / University of Economics, Prague, Faculty of Business Administration, Department of Managerial Psychology and Sociology, nám. W. Churchilla 1938/4, 130 67, Praha 3 - Žižkov, Czech Republic.Email: jana.gaskova@vse.cz.

\begin{abstract}
Servant leadership has been anchored in academia on the international level during recent years. However, there is a lack of studies within the Central European region. The aim of this study is to review the concept of servant leadership and examine its relation to work performance. The focus is placed on the supervisor's servant leadership and their relationship with subordinate's in-role and extra-role work performance. Data were collected via a self-report questionnaire based on validated and adapted scales. The sample included 106 Master students of a standard Management program at the University of Economics, Prague (VŠE) who have a job of 20 hours a week and more. Regression analysis showed a positive and significant relationship between supervisor's servant leadership and both subordinate's in-role and extra-role work performance. On the level of individual dimensions of servant leadership, only "empowering" showed to be positively and significantly related to work performance. Results suggest that working business students appreciate when supervisor provides them with responsibility and autonomy. The implications are limited due to the design of the study and the nature of the data. Organisations would benefit from the adoption of servant leadership if they aim to create an environment supportive for both inrole and extra-role work performance.

Implications for Central European audience: Servant leadership is a viable concept used and researched worldwide. Its factorial structure was supported in the Czech context, and it provides a base for future research. Servant leadership might offer a convenient roadmap to accommodate work expectations of millennials and Gen Z from Central European region, e.g. servant leadership behaviour "creating value for the community" aligns with their expectation "business leaders take responsibility for societal needs".
\end{abstract}

Keywords: servant leadership; work performance; organisational citizenship behaviour JEL Classification: M10

\section{Introduction}

Leaders are often perceived as heroes who will save society or an organisation (Forsyth, 2010). Such a perception might have proven useful when our environment was less complex, but nowadays, companies need to capitalise on the "everyone as leader" approach (Ashford \& DeRue, 2012). Not only rapid technological changes disrupt traditional paradigms, but also 
societal and ecological challenges demand adjustment of business strategies and overall approach to leaders. In addition, several corporate scandals (Enron, Lehman Brothers, Volkswagen) contributed to an increased interest in ethical and moral behaviour among the diverse range of organisations and academia. It resulted in post-heroic models of leadership (Alimo-Metcalfe, 2013), such as ethical, authentic and servant leadership. The latest might be a potential reply to 21 st-century challenges (Northouse, 2016) given its focus on followers' personal and professional growth, transparent work environment and care for the community.

Although the paradoxical title and often moralistic tone can drive practitioners away, several successful organisations benefited from the application of servant leadership philosophy even before it gained more attention within academia. American company Southwest Airlines is used as an example in one of Northouse's (2016) case studies. It was profitable for more than 35 consecutive years while putting the primary focus on employees first, then the needs of the passengers. Attention was also on egalitarianism and humour. Smaller Norwegian IT company Miles reflected the same principles which helped to its business success. It aimed to create an excellent workplace for its employees using servant leadership as its essential philosophy (Bogsnes, 2016; Kolářová, 2016).

Servant leadership is a theory that originated from an essay of practitioner Robert Greenleaf. His work had set a general frame of servant leadership theory. Many authors provided various conceptualisations of servant leadership building on a quote from Greenleaf's essay The Servant as Leader (1977): "The servant-leader is servant first [...] It begins with the natural feeling that one wants to serve, to serve first. Then conscious choice brings one to aspire to lead.". However, following empirical studies varied in solid rationalisation, which led to poor or fragmented conceptualisation as well as inadequate measurement.

Recently, Eva et al. (2018) offered a new definition of servant leadership: "Servant leadership is a (1) other-oriented approach to leadership (2) manifested through one-on-one prioritising of follower individual needs and interests, (3) and outward reorienting of their concern for self towards concern for others within the organisation and the larger community.". Authors aimed to align understanding of servant leadership in terms of its key components. The definition begins with the primary personal motivation of a servant leader, which is the altruistic one. Leader's personal agenda is given a lower priority in comparison with followers' needs. Secondly, the emphasis is on attending these needs in order to elevate each follower to their best possible selves. Lastly, the servant leader seeks to transform followers into servant leaders in the long term with the purpose of their empowerment to contribute to the larger community.

Servant leadership became more researched due to several reasons. Its counterintuitive approach to power and influence is unique within leadership theories. It calls attention to a larger perspective beyond the organisation, which might help to target ecological and societal challenges. Empirical research is enhanced by available rigorous measures of servant leadership (Liden et al., 2008; Sendjaya et al., 2008; Van Dierendonck \& Nuijten, 2011). Research on servant leadership has been flourishing. The recent systematic review included 285 articles spanning 20 years $(1998-2018)$ with over 100 articles published in the last four years (Eva et al., 2018). Authors call for future research to further support conceptual clarity and empirical advancement. 
Firstly, this paper aimed to review the concept of servant leadership in order to support its further research in the Central European region. Secondly, it tested the factorial structure of widely used servant leadership measure SL-28 (Liden et al., 2008) in the Czech context. Thirdly, it examined the relationship between supervisor's servant leadership and subordinate's in-role and extra-role work performance of working Czech business students in order to address study's main research question: What is the relation between servant leadership and work performance?

The need for this line of research is visible from a lack of studies from the Central European region. Eva et al. (2018) reported only one Slovenian study from our region compared to 64 studies from North America and 41 studies from the whole of Europe (including Slovenia). There were also 12 studies with samples from multiple countries. The intention of this paper is to stimulate discussion of the concept within practitioners in the Central European region and to provide a solid base for future research in the Czech context.

\section{Servant leadership framed against leadership theory}

An academic study of leadership emerged at the beginning of the 20th century and has been flourishing with new theories and models ever since. The contemporary abundance of leadership theories might lead us to question whether available approaches bring anything theoretically and empirically novel and useful. How does servant leadership contribute to leadership theory and practice? We will use Alimo-Metcalfe's (2013) five principal stages of leadership theory in order to review the concept of servant leadership.

Pioneers of the leadership research focused on personal qualities and traits of leaders with a predominant belief that leaders were born. The first stage of the "trait" theories lacked quality psychometric testing in the 1900s and following years leading to inactivity in 1960s until it re-emerged after a long pause in 1990s (Day \& Antonakis, 2012). Leader's character is studied as an antecedent of servant leadership behaviour. Leader's motivation to serve others and moral maturity is often part of proposed antecedents. There is empirical evidence for a positive relationship between servant leadership and leader's low narcissism (Peterson et al., 2012), agreeableness and low extraversion (Hunter et al., 2013).

The second stage of leadership theory was directed at the leader's behaviours (the "behavioural" approach). The most influential studies were those conducted at Ohio State University and at the University of Michigan, which resulted in two central factors: consideration (person-oriented leadership) and initiating structure (task-oriented leadership). The approach was short-lived due to a lack of consistent findings. However, Judge et al. (2004) supported the validity of these two dimensions in their meta-analysis. Behavioural approach functioned as a bridge towards contingency and more recent theories, such as servant leadership which is mainly described through dimensions of leader's behaviours with further advancement, e.g. in terms of ethical and community-focused dimensions.

Contingency and situational approaches represent the third stage of leadership research which was developed in the 1960s and 1970s. It introduced contextual variables such as follower's characteristics, task characteristics or clarity of paths to follower goals. Managers were encouraged to be flexible in their approach. In addition, a line of research looked into the nature of the relationship between leader and their followers which evolved into the leader-member exchange (LMX) theory (Graen \& Uhl-Bien, 1995). It is mainly described by high-quality relationships that refer to the high degree of mutual trust and respect between 
leader and follower (the "in group") and low-quality relationships that are based mainly on the economic exchange between leader and follower. Day \& Antonakis (2012) concluded that contingency theories were generally inactive since the 2000s as opposed to LMX, which gained an increased interest in top journals (e.g. The Leadership Quarterly). Servant leadership theory taps into the third stage, mainly in order to complete its conceptual model with regard to moderation and mediation variables and different outcomes.

Alimo-Metcalfe (2013) suggested that "charismatic-inspirational" models, or the new leadership school (Day \& Antonakis, 2012), were developed as a response to several global challenges such as the recession after the oil crisis in 1973 and growing competition from East Asian economies. Several authors believed in need of paradigm shift away from a transactional approach. Bass (1985) built on previous work (e.g. Burns, 1978) and introduced a new type of leadership known as transformational leadership. Leaders were viewed as ones who helped followers to go beyond their own interests. His model included dimensions such as idealised influence, inspirational motivation, intellectual stimulation, and individualised consideration. One of the main differences from servant leadership can be found in leaders' priorities. Transformational leaders strive to align the interests of all stakeholders and also their own, on the other hand, servant leaders put the needs of others, mainly followers, as their highest priority (Bass, 2000). Even though "neo-charismatic" models prevailed the leadership research in 2000 s, their dominance has been weakened by the next stage of postheroic models.

The fifth and the last stage of post-heroic models react to the global banking crisis and covers a wide range of leadership theories which emphasise leadership as a dynamic social process. Alimo-Metcalfe (2013) mentioned a shift from "leadership done to others" to "leadership with others". We will focus particularly on ethical and authentic leadership. Ethical leadership refers to ethical standards which are not only espoused internally by a leader, but also demonstrated and reinforced. Authentic leadership shares an aspect of internalised moral perspective with ethical leadership. In addition, it distinguishes factors such as leader selfawareness, relational transparency and balanced processing (Walumbwa et al., 2008). Each approach adds a new perspective to a transactional and transformational approach to leadership. However, both showed lower utility compared to transformational leadership unless used to study very specific outcomes (Hoch et al., 2018). Servant leadership could be perceived as a higher-order construct which includes not only a moral perspective but also focuses on the development of followers and community. Hoch et al. (2018) showed in their meta-analysis that servant leadership appears to be more promising as a stand-alone leadership theory due to its wider explanatory power of different outcomes (especially organisational citizenship behaviour, job satisfaction, trust or LMX) and lower correlation with transformational leadership (.52) compared to ethical (.70) and authentic (.75) leadership.

Servant leadership successfully builds on previous stages of leadership theory and extends current approaches into the new viable one. Its unique combination of characteristics while being explicit about putting followers first distinguishes it from other theories. Servant leadership also shows incremental validity in comparison to transformational leadership (Banks et al., 2018; Hoch et al., 2018). However, several limitations of existing studies need to be taken into account (e.g. endogeneity bias, common method bias, a small number of studies), thus future research should focus on quality and varied research designs (Eva et al., 2018). 


\section{Measures of servant leadership}

A systematic review by Eva et al. (2018) recommended only three measures of servant leadership behaviour out of 16 that were evaluated based on their theoretical and methodological rigour: Liden et al.'s (2015) SL-7, Sendjaya et al.'s (2008) SLBS-6, and Van Dierendonck and Nuijten's (2011) SLS. Servant Leadership measure (SL-7) by Liden et al. (2015) was valued for its inclusion of the dimension Creating value for the community which incorporates leader's interest in helping the community around the organisation and encouragement of followers to be active themselves. Dimension Conceptual skills also represent unique theorising compared to SLBS-6 and SLS. Initial Servant Leadership measure SL-28 included 28 items (4 items for each dimension) and was validated by Liden et al. (2008).

Behaviours of servant leader represent the core of the servant leadership. Liden et al. (2008) identified seven dimensions which are distinct from each other and create a multidimensional construct:

- Conceptual skills - a thorough insight into organisation's purpose as well as day-today operations, ability to solve complex problems.

- Empowering - support of followers to effectively think and act on their own.

- Helping followers grow and succeed - knowing followers' aspirations and helping them to accomplish personal and career growth, e.g. via mentoring.

- $\quad$ Putting followers first - prioritisation of followers' needs.

- Behaving ethically - enhancement of transparent workplace by demonstration of honest communication and sticking to high ethical standards.

- Emotional healing - sensitivity to well-being of others.

- $\quad$ Creating value for the community - giving back to the community.

Taken together, understanding of servant leadership has become more unified in academia. Servant leadership research has recently gone through phases of the conceptual and measurement development entering the model development phase (Eva et al., 2018). Both researchers and practitioners from the Central European region can benefit from getting involved in a current upward tendency of the field.

Based on the successful use of theorising and measure of Liden and colleagues in various studies (Donia et al., 2016; Hu \& Liden, 2011; Panaccio et al., 2015), it can be expected that the factor structure of SL-28 will be replicable in the Czech Republic. It has already been adopted via back-translation and tested at a student sample (Kolářová \& Honsová, 2017; Kolářová et al., 2016).

Hypothesis 1: The factorial structure of the SL-28 will be supported in the Czech context.

\section{Servant leadership and work performance}

This article is focused on the relationship of supervisor's servant leadership and subordinate's work performance, namely in-role and extra-role work performance. It covers categorisation that can be applied to any position. In-role work performance (or task performance) can be described as a task-related proficiency which origins from a job description (Viswesvaran \& Ones, 2000). Extra-role work performance (or organisational citizenship behaviour) captures 
individual activities which are beyond formal requirements of employee's job description (Viswesvaran \& Ones, 2000).

On the level of individual and group follower behavioural outcomes, organisational citizenship behaviours (OCB) belong to the most examined (Hunter et al., 2013; Panaccio et al., 2015; Walumbwa et al., 2010). OCB can be focused on the community, co-workers, customers, organisation or individual. Both systematic review by Eva et al. (2018) and meta-analysis by Hoch et al. (2018) included only 16 articles studying the relationship between servant leadership and OCB. Donia et al. (2016) didn't find support for a positive relationship between servant leadership and subordinates' OCB. The present study aims to broaden extant research in this field. Reported OCB is directed towards the working group of the subordinate, and it is referred to as the extra-role work performance.

Hypothesis 2: Supervisor's servant leadership will be positively associated with subordinates' in-role work performance.

Hypothesis 3: Supervisor's servant leadership will be positively associated with subordinates' extra-role work performance.

In conclusion, the study aims to test the factorial structure of the Czech version of SL-28 developed by Liden et al. (2008) and adapted by Kolářová et al. (2016). Additionally, relations between perceived servant leadership behaviours of supervisor and subordinate's work performance (in-role, extra-role) are explored in the Czech context.

\section{Methods}

\subsection{Participants}

The sample consisted of 106 Master students of a standard Management program at the University of Economics, Prague (VŠE). Data collection took place in December 2016 and resulted in 231 responses. Only respondents with a job workload of 20 hours a week and more were retained (107 respondents). It was a convenient sample with a diverse occupational background. One outlier was detected during the assessment of the regression model and erased, which resulted in a final sample of 106 respondents.

There were 48 men (45\%) and 58 women (55\%) in the final sample. All have a bachelor degree while being part of the Master's program. The majority were students at the Faculty of Business Administration (101 cases), four students were from other faculties at the university, and one case has a missing value. Average work experience was 4 years. The average age was 23 years. Description of evaluated leaders is in Table 1. There were 60 evaluated supervisors who were men and 46 who were women. Average time spent on a job was 16 months. Average time spent on the job with an evaluated person was 15 months.

Table 1 | Groups of students based on the type of evaluated leader

\begin{tabular}{lcc}
\hline Type of evaluated leader & $\mathbf{n}$ & $\%$ \\
\hline Direct supervisor in a current job & 66 & 62 \\
Direct supervisor in a previous job & 35 & 33 \\
Not a direct supervisor but evaluated student's work performance & 5 & 5 \\
\hline
\end{tabular}

Source: author. Note: $n=106$. 


\subsection{Procedure and measures}

Data were collected via a questionnaire administered by trained researchers. Participants were informed about the research, and it was emphasised that the participation was voluntary. The questionnaire was presented as a part of a PhD project on servant leadership. There was also an introductory text which asked participants to answer all questions as accurately as possible. It was a paper-based questionnaire to be filled out anonymously in order to guarantee confidentiality.

The questionnaire consisted of the full version of Servant Leadership measure (SL-28) by Liden et al. (2008), in-role job performance by Kuvaas and Dysvik (2009) and extra-role job performance by Van Dyne and LePine (1998). Adaptation of all items to Czech followed the back-translation procedure, a verification of understanding during personal interviews and finally a pilot study (see Kolářová et al. (2016) for more information). Each item was measured on a 5-point Likert scale: strongly disagree (1), slightly disagree (2), neutral (3), slightly agree (4), strongly agree (5). All items were positively formulated. Participants were asked to refer to a person who evaluated their job, be it a direct or indirect supervisor.

Servant Leadership measure (SL-28). The scale was made up of 28 items measuring 7 correlated dimensions which were based on theorising by Liden et al. (2008). Each dimension consisted of 4 items. Examples were as follows: (1.) Conceptual skills: 'My supervisor can tell if something work-related is going wrong.'; (2.) Empowering: 'My supervisor encourages me to handle important work decisions on my own.'; (3.) Helping followers grow and succeed: 'My supervisor makes my career development a priority.'; (4.) Putting followers first: 'My supervisor seems to care more about my success than his/her own.'; (5.) Behaving ethically: 'My supervisor holds high ethical standards.'; (6.) Emotional healing: 'I would seek help from my supervisor if I had a personal problem.'; (7.) Creating value for the community: 'My supervisor emphasises the importance of giving back to the community'.

In-role work performance. The measure was developed by Kuvaas \& Dysvik (2009) and consisted of 10 items. There were two dimensions: work effort ( 5 items) and work quality (5 items). Examples were: work effort: 'I try to work as hard as possible.'; work quality: 'The quality of my work is usually high.'.

Extra-role work performance. This variable was measured with seven items developed by Van Dyne \& LePine (1998). It referred to individual behaviours that are discretionary. It is also known as the construct 'Organizational Citizenship Behavior' (OCB). An example was: 'I volunteer to do things for my workgroup.'.

\subsection{Data analysis}

Software $R$ was used for the data analysis. First of all, data were tested based on assumptions of normality. Descriptive statistics and basic correlations are available. Furthermore, servant leadership was investigated in terms of its individual dimensions. Secondly, regression analysis was conducted in order to see how not only demographic variables but also individual dimensions, influence the relationship between servant leadership and work performance. 


\section{Results}

Before execution of the main analyses, check of the skewness and kurtosis of the individual items was carried out. Majority of all items fell between -1.00 and +1.00 with few minor exceptions out of the range (skewness: 3 items (7\%), kurtosis: 3 items (7\%)). The distribution was significantly different from a normal distribution as all items showed $p$-values less than 0.001 in Shapiro-Wilk test. Thus, it was important to choose the following statistical tests accordingly, e.g. Spearman's test.

Variables were aggregated on the level of their items' mean values. The distribution was normal for all variables. P-values of Shapiro-Wilk test were higher than 0.01 . Each variable passed reliability test measured by Cronbach alpha. Descriptive statistics and correlation matrix are in Table 2.

Table 2 | Descriptions and intercorrelations of the main constructs

\begin{tabular}{lccccc}
\hline Variables & $\mathbf{M}$ & SD & $\mathbf{1}$ & $\mathbf{2}$ & $\mathbf{3}$ \\
\hline 1. Servant leadership & 3.35 & .65 & $(0.94)$ & & \\
2. In-role work performance & 3.84 & .56 & $0.41^{* * *}$ & $(0.84)$ & \\
3. Extra-role work performance & 3.80 & .57 & $0.31^{* *}$ & $0.50^{* * *}$ & $(0.78)$ \\
\hline
\end{tabular}

Source: author. Note: $\mathrm{n}=106$. Cronbach alpha is within brackets. Pearson's correlation coefficient. ${ }^{* *} p<.01,{ }^{* * *} p<.001$.

Two dimensions of servant leadership behaviour had non-normally distributed data (Conceptual skills, Behaving ethically) when tested by Shapiro-Wilk test $(p<0.001)$. Intercorrelations among individual dimensions were of medium to large effect. Specific values are part of Table 3. Correlations are not too high $(r>.80)$ in neither correlation matrix. Conceptual skills as the highest-ranking dimension are not surprising given that students ranked their supervisors. A person in such a role is expected to have a thorough insight into the organisation's purpose as well as day-to-day operations and the ability to solve complex problems. On the other hand, Creating value for the community and Putting followers first were the lowest-ranking dimensions.

Table 3 also shows positive correlations between servant leadership dimensions and both inrole and extra-role work performance. Their highest correlation is reported with Empowering.

Bartlett's test for SL-28 was significant, and the KMO test yielded a degree of common variance meritorious (KMO $=0.885)$. Further factor analysis is appropriate. Lavaan version 0.6-3 (Rosseel, 2012) in $\mathrm{R}$ version 3.5.1 (R Core Team, 2018) was used for CFA. Latent factors were standardised, allowing free estimation of all factor loadings. The model was on the edge of acceptable value .9 with a CFI .874 and TLI .856 . The model had a close fit with RMSEA of $.073(90 \% \mathrm{Cl}$ from .06 to .08$)$ and SRMR of .076 . The full seven-factor model fit the data significantly better than a single-factor solution $\left(x^{2}(21)=267.46, p<.001\right)$. Singlefactor solution assumed that all 28 items loaded on a single servant leadership latent factor $\left(\mathrm{X}^{2}(350)=781.133, \mathrm{p}<.001, \mathrm{CFI}=.707, \mathrm{TLI}=.683\right.$, RMSEA=.108, SRMR=.902). The results were unsatisfactory, therefore supporting the multifactor structure of SL-28. It is possible to assume that the seven-dimensional model of the SL-28 is supported by data collected in the sample. 
Table 3 | Descriptive statistics and correlation matrix

\begin{tabular}{|c|c|c|c|c|c|c|c|c|c|}
\hline Variables & $\mathbf{M}$ & SD & 1 & 2 & 3 & 4 & 5 & 6 & 7 \\
\hline 1. Conceptual skills & 3.98 & .80 & $(.80)$ & & & & & & \\
\hline 2. Empowering & 3.54 & .79 & 0.49 & $(.74)$ & & & & & \\
\hline $\begin{array}{l}\text { 3. Helping followers } \\
\text { grow and succeed }\end{array}$ & 3.44 & .95 & 0.63 & 0.58 & $(.85)$ & & & & \\
\hline 4. Putting followers first & 2.65 & .76 & 0.52 & 0.53 & 0.65 & (.79) & & & \\
\hline 5. Behaving ethically & 3.60 & .82 & 0.37 & 0.32 & 0.42 & 0.64 & $(.79)$ & & \\
\hline 6. Emotional healing & 3.44 & .82 & 0.53 & 0.48 & 0.68 & 0.62 & 0.64 & $(.72)$ & \\
\hline $\begin{array}{l}\text { 7. Creating value } \\
\text { for the community }\end{array}$ & 2.82 & .84 & 0.45 & 0.40 & 0.50 & 0.55 & 0.63 & 0.63 & $(.82)$ \\
\hline $\begin{array}{l}\text { In-role work } \\
\text { performance }\end{array}$ & 3.84 & .56 & 0.24 & 0.48 & 0.34 & 0.40 & 0.30 & 0.37 & 0.26 \\
\hline $\begin{array}{l}\text { Extra-role work } \\
\text { performance }\end{array}$ & 3.80 & .57 & 0.20 & 0.37 & 0.14 & 0.30 & 0.32 & 0.28 & 0.33 \\
\hline
\end{tabular}

Source: author. Note: $\mathrm{n}=106$. Cronbach alpha is within brackets. Spearman's correlation coefficient.

Hypotheses 2 and 3 focused on the relationship of supervisor's servant leadership and inrole and extra-role work performance perceived by subordinates. Table 4 presents the results of those models. Servant leadership explained $22 \%$ of the variance in in-role work performance. Only "empowering" dimension was positively and significantly related to in-role work performance ratings $(\beta=.37, p<.001$ ). Servant leadership explained $15 \%$ of the variance in extra-role work performance. Again, only "empowering" dimension was positively and significantly related to extra-role work performance ratings $(\beta=.34, p<.01)$. Together, the results provide support for both hypotheses 2 and 3 .

Table 4 | Regression analysis with SL-28 dimensions predicting work performance

\begin{tabular}{|c|c|c|c|c|}
\hline \multirow{2}{*}{ Variables } & \multicolumn{2}{|c|}{$\begin{array}{c}\text { In-role } \\
\text { work performance }\end{array}$} & \multicolumn{2}{|c|}{$\begin{array}{c}\text { Extra-role } \\
\text { work performance }\end{array}$} \\
\hline & B (SE) & $\beta$ & B (SE) & $\beta$ \\
\hline (Intercept) & $2.581(.30)$ & & $2.794(.32)$ & \\
\hline Conceptual skills & $-0.106(.08)$ & -.152 & $-0.032(.09)$ & -.044 \\
\hline Empowering & $0.260(.08)$ & $.369^{\star \star \star}$ & $0.242(.08)$ & $.335^{\star *}$ \\
\hline $\begin{array}{l}\text { Helping followers grow and } \\
\text { succeed }\end{array}$ & $-0.030(.08)$ & -.051 & $-0.176(.09)$ & $-.294^{\dagger}$ \\
\hline Putting followers first & $0.133(.10)$ & .182 & $0.079(.11)$ & .106 \\
\hline Behaving ethically & $0.006(.09)$ & .009 & $0.010(.10)$ & .014 \\
\hline Emotional healing & $0.136(.10)$ & .200 & $0.075(11)$ & .108 \\
\hline $\begin{array}{l}\text { Creating value for the } \\
\text { community }\end{array}$ & $-0.007(.08)$ & -.011 & $0.147(.09)$ & .218 \\
\hline $\mathbf{F}$ & $5.278^{* * *}$ & & $3.684^{* *}$ & \\
\hline $\mathbf{R}^{2}$ & 0.274 & & 0.208 & \\
\hline
\end{tabular}

Source: author. Note: $\mathrm{n}=106$. All VIF coefficients $<2.913 .{ }^{\dagger} p<.10,{ }^{* *} p<.01,{ }^{* \star *} p<.001$.

\section{Discussion}


This paper set out to study servant leadership in the Czech Republic. Servant leadership theory originated within the United States, and although research interest in that area has been growing in recent years, research in the Central European region has been scarce. Van Dierendonck et al. (2017) showed that servant leadership could be measured internationally and cross-culturally in Europe. However, their study lacked countries from the region of Central Europe. Our findings bring encouraging results that support their conclusion in the Czech Republic, even though tested for a different measure (SL-28). Factorial validity was supported with a sample of 106 working business students.

Both hypotheses about the positive relationship between supervisor's servant leadership and subordinate's in-role and extra-role work performance were supported. It is consistent with prior findings (Hu \& Liden, 2011; Walumbwa et al., 2010). This study is the first to explore the relationship of servant leadership with work performance in the Czech Republic. Findings of our study are in line with the conclusion of the recent review by Eva et al. (2018) in terms of the positive relationship between servant leadership and several behavioural outcomes.

Results of regression analyses also support the positive and significant relationship of "empowering" dimension of servant leadership with work performance. It might indicate that working students in the beginning of their career are the most susceptible to behaviour that helps them become autonomous at their workplace. Fischerova (2019) showed that a group with the majority of students from the standard Management program at the University of Economics, Prague (VŠE) regard independence as the third most important life value (out of 14). Such a result in context with our research might help us to understand why the supervisor's empowering behaviour plays a significant role in a relationship with both in-role and extra-role work performance. On the other hand, we cannot generalise our findings given the specific background of the sample. Fischerova (2019) also showed that groups with the majority of students and alumni from the selective program CEMS MIM at the University of Economics, Prague (VŠE) have significantly differed from the group with the majority of students from the standard Management program in terms of their life values.

Future research can investigate whether CEMS MIM students and alumni also differ in terms of the perception of servant leadership compared to standard business students and alumni. They might be particularly more sensitive to servant leadership style given that "concern for the environment" was among their most important life values.

According to a report from Deloitte (2019), millennials (born 1983-1994) and Gen Z (born 1995-2002) differed from older generations as they expected organisations and business leaders to take responsibility for societal needs. Report's conclusion also included suggestions for leaders such as to open a dialogue with their young employees, to enable people to realise their ambitions and to provide them with the training needed to succeed. Servant leadership might provide a convenient roadmap given its dimensions such as "creating value for the community", "emotional healing" and "helping followers grow and succeed".

Van Dierendonck et al. (2017) shortened their version of a questionnaire SLS from eight to five dimensions and yet kept empowerment as an important dimension to servant leadership concept. Liden et al. (2015) kept all dimensions of SL-28, including Empowering. However, a criticised feature of leadership theories is that number of them are redundant. Empowering leadership is a stand-alone construct that has been researched, and findings showed a 
positive relationship to various outcome variables (Humborstad et al., 2014). Researchers may want to study closer which dimensions of servant leadership are truly unique to servant leadership and what kind of a role "empowering" has.

Organisations would benefit from the adoption of servant leadership if they aim to create an environment supportive for both in-role and extra-role work performance. Servant leadership can be compared to a vitamin contributing to a high-quality organisational life. However, it is not a panacea and should not be treated as antibiotics that will save a seriously infected organisation. Training programmes targeted at increasing leader's emotional intelligence and ethical behaviour could help to develop their servant leadership and consequently more engaged followers.

There are several limitations of the study due to its design and the nature of the data. Firstly, we cannot infer any strong causal relationship due to a cross-sectional design. Future research should focus on a longitudinal design in order to study cause and effect. Secondly, all data are based on self-report questionnaires which can raise concerns about common method bias. Several steps were taken to minimise this limitation ex-ante (e.g. an introductory note about anonymisation of data, counterbalancing the order of questions) (Chang et al., 2010). Thirdly, the sample cannot be considered as representative of neither the Czech population, nor Czech students, as it was not the purpose of our research. However, given the fact that respondents have working experience of more than 20 hours a week, HR practitioners can infer suggestions for their business activities. Conclusions are specific to working business students of a standard Master program of Management at the University of Economics, Prague (VŠE).

\section{Conclusion}

Taken as a whole, the present paper contributes to the servant leadership research in several ways. First of all, servant leadership was framed against leadership theory in order to show how it builds on previous knowledge and findings. Secondly, it shows that measure SL-28 can be used in the Czech Republic for future research. Thirdly, it extends findings of the relationship between servant leadership and work performance supporting previous research. There was no particular dimension that would stand out except for "empowering" which was positively and significantly related to both in-role and extra-role work performance. Companies hiring business students may want to pay attention to how their leaders enable employees to take more responsibility and become more autonomous. Such an approach might help them to solve the leadership talent crisis (Ashford \& DeRue, 2012).

\section{Acknowledgement}

The study was supported by the Internal Grant Agency of the University of Economics, Prague, as a part of project number F3/24/2016.

\section{References}

Alimo-Metcalfe, B. (2013). A Critical Review of Leadership Theory. In H. S. et al. Leonard (Ed.), The Wiley-Blackwell Handbook of the Psychology of Leadership, Change, and Organizational Development (pp. 15-47). John Wiley \& Sons.

Ashford, S. J., \& DeRue, D. S. (2012). Developing as a leader. Organizational Dynamics, 41(2), 146154. https://doi.org/10.1016/j.orgdyn.2012.01.008 
Banks, G. C., Gooty, J., Ross, R. L., Williams, C. E., \& Harrington, N. T. (2018). Construct redundancy in leader behaviors: A review and agenda for the future. The Leadership Quarterly, 29(1), 236251. https://doi.org/10.1016/j.leaqua.2017.12.005

Bass, B. M. (1985). Leadership and Performance beyond Expectations. The Free Press.

Bass, B. M. (2000). The Future of Leadership in Learning Organizations. Journal of Leadership \& Organizational Studies, 7(3), 18-40. https://doi.org/10.1177/107179190000700302

Bogsnes, B. (2016). Implementing Beyond Budgeting: Unlocking the Performance Potential (2nd Editio). John Wiley \& Sons.

Burns, J. M. (1978). Leadership. Harper.

Chang, S.-J., van Witteloostuijn, A., \& Eden, L. (2010). From the Editors: Common method variance in international business research. Journal of International Business Studies, 41(2), 178-184. https://doi.org/10.1057/jibs.2009.88

Day, D. V., \& Antonakis, J. (2012). Leadership: Past, Present, and Future. In D. V. Day \& J. Antonakis (Eds.), The nature of leadership. Sage Publications.

Deloitte. (2019). The Deloitte Global Millennial Survey 2019. Retrieved June 30, 2020, from https://www2.deloitte.com/content/dam/Deloitte/global/Documents/About-Deloitte/deloitte-2019millennial-survey.pdf

Donia, M. B. L., Raja, U., Panaccio, A., \& Wang, Z. (2016). Servant leadership and employee outcomes: the moderating role of subordinates' motives. European Journal of Work and Organizational Psychology, 25(5), 722-734. https://doi.org/10.1080/1359432X.2016.1149471

Eva, N., Robin, M., Sendjaya, S., van Dierendonck, D., \& Liden, R. C. (2018). Servant Leadership: A systematic review and call for future research. The Leadership Quarterly, July, 1-22. https://doi.org/10.1016/j.leaqua.2018.07.004

Fischerova, M. (2019). Analýza hodnot a kariérových dovedností studentů a absolventů vybraných manažerských programů [Doctoral dissertation, Vysoká škola ekonomická v Praze]. https://theses.cz/id/60a206/

Forsyth, D. R. (2010). Group Dynamics (5th ed.). Cengage Learning.

Graen, G. B., \& Uhl-Bien, M. (1995). Relationship-based approach to leadership: Development of leader-member exchange (LMX) theory of leadership over 25 years: Applying a multi-level multidomain perspective. Leadership Quarterly, 6(2), 219-247. https://doi.org/10.1016/10489843(95)90036-5

Greenleaf, R. K. (1977). The Servant as Leader. In Servant Leadership: a journey into the nature of legitimate power and greatness (p. 338). Paulist Press.

Hoch, J. E., Bommer, W. H., Dulebohn, J. H., \& Wu, D. (2018). Do Ethical, Authentic, and Servant Leadership Explain Variance Above and Beyond Transformational Leadership? A MetaAnalysis. Journal of Management, 44(2), 501-529. https://doi.org/10.1177/0149206316665461

Hu, J., \& Liden, R. C. (2011). Antecedents of team potency and team effectiveness: An examination of goal and process clarity and servant leadership. Journal of Applied Psychology, 96(4), 851-862. https://doi.org/10.1037/a0022465

Humborstad, S. I. W., Nerstad, C. G. L., \& Dysvik, A. (2014). Empowering leadership, employee goal orientations and work performance. Personnel Review, 43(2), 246-271. https://doi.org/10.1108/PR-01-2012-0008

Hunter, E. M., Neubert, M. J., Perry, S. J., Witt, L. A., Penney, L. M., \& Weinberger, E. (2013). Servant leaders inspire servant followers: Antecedents and outcomes for employees and the organisation. The Leadership Quarterly, 24(2), 316-331.

https://doi.org/10.1016/j.leaqua.2012.12.001

Judge, T. A., Piccolo, R. F., \& llies, R. (2004). The Forgotten Ones? The Validity of Consideration and Initiating Structure in Leadership Research. Journal of Applied Psychology, 89(1), 36-51. https://doi.org/10.1037/0021-9010.89.1.36 
Kolářová, J. (2016). Servant leadership. In E. Jarošová, D. Pauknerová, \& H. Lorencová (Eds.), Nové trendy v leadershipu: Koncepce, výzkumy, aplikace (pp. 114-131). Management Press.

Kolářová, J., \& Honsová, P. (2017). Adaptace dotazníku SL-28 do češtiny. In A. Gregar \& M. Horák (Eds.), Psychologie práce a organizace 2017: Pracovní potenciál a jeho proměny $v$ čase (pp. 291-300). https://doi.org/ISBN 978-80-7454-714-0

Kolářová, J., Honsová, P., \& Konvalinka, M. (2016). Translation and adaptation of servant leadership questionnaire into Czech language. In T. Löster \& T. Pavelka (Eds.), The 10th International Days of Statistics and Economics (pp. 882-892). Libuše Macáková, MELANDRIUM. https://msed.vse.cz/msed_2016/article/131-Kolarova-Jana-paper.pdf

Kuvaas, B., \& Dysvik, A. (2009). Perceived investment in employee development, intrinsic motivation and work performance. Human Resource Management Journal, 19(3), 217-236. https://doi.org/10.1111/j.1748-8583.2009.00103.x

Liden, R. C., Wayne, S. J., Meuser, J. D., Hu, J., Wu, J., \& Liao, C. (2015). Servant leadership: Validation of a short form of the SL-28. The Leadership Quarterly, 26(2), 254-269. https://doi.org/10.1016/j.leaqua.2014.12.002

Liden, R. C., Wayne, S. J., Zhao, H., \& Henderson, D. (2008). Servant leadership: Development of a multidimensional measure and multi-level assessment. The Leadership Quarterly, 19(2), 161177. https://doi.org/10.1016/j.leaqua.2008.01.006

Northouse, P. G. (2016). Leadership: theory and practice (Seventh ed). Sage.

Panaccio, A., Henderson, D. J., Liden, R. C., Wayne, S. J., \& Cao, X. (2015). Toward an Understanding of When and Why Servant Leadership Accounts for Employee Extra-Role Behaviors. Journal of Business and Psychology, 30(4), 657-675. https://doi.org/10.1007/s10869-014-9388-z

Peterson, S. J., Galvin, B. M., \& Lange, D. (2012). CEO Servant Leadership: Exploring Executive Characteristics and Firm Performance. Personnel Psychology, 65(3), 565-596. https://doi.org/10.1111/j.1744-6570.2012.01253.x

R Core Team. (2018). R: A language and environment for statistical computing. R Foundation for Statistical Computing. https://www.r-project.org/

Rosseel, Y. (2012). lavaan: An R Package for Structural Equation Modeling. Journal of Statistical Software, 48(2), 1-36. http://www.jstatsoft.org/v48/i02/

Sendjaya, S., Sarros, J. C., \& Santora, J. C. (2008). Defining and measuring servant leadership behaviour in organisations. Journal of Management Studies, 45(2), 402-424. https://doi.org/10.1111/j.1467-6486.2007.00761.x

van Dierendonck, D., \& Nuijten, I. (2011). The Servant Leadership Survey: Development and Validation of a Multidimensional Measure. Journal of Business and Psychology, 26(3), 249-267. https://doi.org/10.1007/s10869-010-9194-1

Van Dierendonck, D., Sousa, M., Gunnarsdóttir, S., Bobbio, A., Hakanen, J., Pircher Verdorfer, A., Cihan Duyan, E., \& Rodriguez-Carvajal, R. (2017). The Cross-Cultural Invariance of the Servant Leadership Survey: A Comparative Study across Eight Countries. Administrative Sciences, 7(2), 8. https://doi.org/10.3390/admsci7020008

Van Dyne, L., \& LePine, J. A. (1998). Helping and Voice Extra-Role Behaviors: Evidence of Construct and Predictive Validity. Academy of Management Journal, 41(1), 108-119. https://doi.org/10.2307/256902

Viswesvaran, C., \& Ones, D. S. (2000). Perspectives on Models of Job Performance. International Journal of Selection and Assessment, 8(4), 216-226. https://doi.org/10.1111/1468-2389.00151

Walumbwa, F. O., Avolio, B. J., Gardner, W. L., Wernsing, T. S., \& Peterson, S. J. (2008). Authentic Leadership: Development and Validation of a Theory-Based Measure. Journal of Management, 34(1), 89-126. https://doi.org/10.1177/0149206307308913

Walumbwa, F. O., Hartnell, C. A., \& Oke, A. (2010). Servant leadership, procedural justice climate, 
service climate, employee attitudes, and organisational citizenship behavior: A cross-level investigation. Journal of Applied Psychology, 95(3), 517-529. https://doi.org/10.1037/a0018867

The research paper passed the review process. | Received: January 8, 2020; Revised: February 21, 2020; Accepted: February 24, 2020; Published: July 10, 2020. 